\title{
Primitive myxoid mesenchymal tumor of infancy in scrotum: A case report and literature review
}

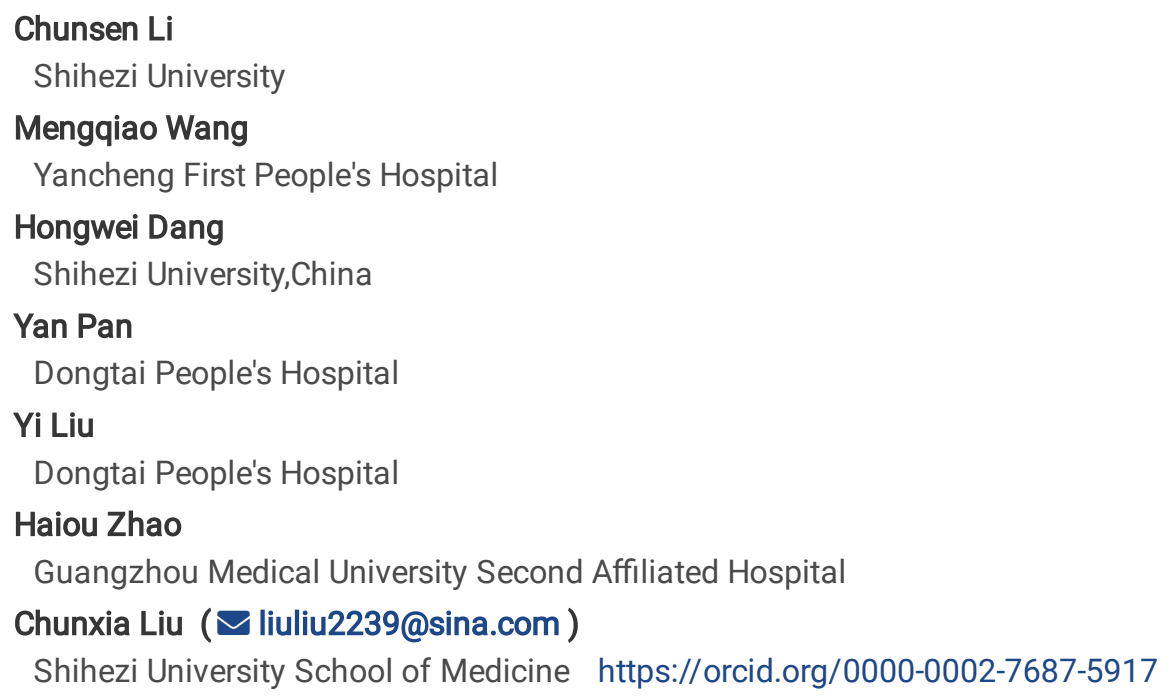

\section{Case Report}

Keywords: Primitive Myxoid Mesenchymal Tumor of Infancy, Immunochemistry BCOR, Molecular genetics

Posted Date: May 11th, 2021

DOI: https://doi.org/10.21203/rs.3.rs-506327/v1

License: (c) (1) This work is licensed under a Creative Commons Attribution 4.0 International License. Read Full License 


\section{Abstract}

Background

Primitive myxoid mesenchymal tumor of infancy (PMMTI) is a rare tumor and its molecular mechanism and prognosis remain unclear. We here report a case of PMMTI, and review the reported literature of PMMTI.

Case presentation

A one-year-old boy found a lump in his right groin. The size of the mass was $1 \mathrm{~cm} \times 1 \mathrm{~cm}$. Computed tomography showed a round, slightly dense shadow of $38 \mathrm{~mm} \times 32 \mathrm{~mm}$ in the right groin. The tumor was removed for pathological examination, and the size of the tumor was $6.0 \mathrm{~cm} \times 5.0 \mathrm{~cm} \times 3.0 \mathrm{~cm}$. Tumor cells are diffusely distributed, mainly spindle cells. The blood vessels were abundant, many adipocytes can be observed in some areas, and focal lymphocyte infiltration can be seen in a few areas. Immunophenotype was as follows: histone H3 at lysine 27 (H3K27me3), B-cell lymphoma 6 corepressor (BCOR) and Bcl-2 were positive, cluster of differentiation 99 (CD99) showed diffuse reactivity, BCL6 was scattered positive, Ki-67 proliferation index was $20 \%$. Dual-color fluorescence in situ hybridization (FISH) showed red and green signal nuclei caused by the deletion of ETV6 gene rearrangement. The patient underwent extensive surgical resection during the recurrence period and was in good condition 7 months later.

\section{Conclusions}

PMMTI is at least a low-grade malignancy. BCOR, BCL2, BCL6, and CD99 can be used as special IHC markers, and most PMMTI cases exhibit BCOR ITD change. H3K27me3 may be used as a new IHC marker for PMMTI.

\section{Introduction}

Primitive myxoid mesenchymal tumor of infancy (PMMTI) was first described as a primitive mesenchymal soft tissue sarcoma without distinctive lineage of differentiation by Allagio et al [1]. To date, less than 40 cases have been reported worldwide. The biological behavior of PMMTI remains unclear and is thought to be an intermediate or low-grade malignancy. This tumor needs to be distinguished from other soft tissue tumors that occur in infants and young children. The different tumors occurring in infancy are congenital-infantile fibrosarcoma (CIFS), embryonal rhabdomyosarcoma (ERMS), clear cell sarcoma of kidney (CCSK), Ewing sarcoma/primitive neuroectodermal tumor (EWS/PNET), and infantile soft tissue undifferentiated round cell sarcoma (ISTURCS).

In this study, we presented a case of an infant with well-defined PMMTI in the scrotum. This is the first reported case of PMMTI occurring in the scrotum. We first reported that the H3K27me3 is positive in PMMTI through immunohistochemical (IHC) staining. We summarized the clinical characteristics of all cases and analyzed the differential diagnosis of tumors, $\mathrm{IHC}$ characteristics, and molecular genetic changes to provide pathologists with several clinical, IHC, and molecular references in the diagnosis and differential diagnosis of tumors.

\section{Case Presentation}

A 1-year-old boy with a large mass in the right scrotum was used as the case study. The patient's parents reported that a mass was found in the right groin 3 months ago. The mass size was $1 \mathrm{~cm} \times 1 \mathrm{~cm}$. Computed tomography examination showed a $38 \mathrm{~mm} \times 32 \mathrm{~mm}$ round-like slightly dense shadow located in the right groin. Compared with the surrounding tissues, the lesion had slightly heterogeneous density (Fig. 1a), and no evidence of distant metastasis was found. The mass was removed for pathologic examination. After 1 month, a nodule was found at the previous operation site (Fig. 1b). Extended surgical resection was then performed for pathologic examination. After 7 months, everything was normal.

The macroscopic dimensions of the primary and secondary tumors were $6.0 \mathrm{~cm} \times 5.0 \mathrm{~cm} \times 3.0 \mathrm{~cm}$ and $5.0 \mathrm{~cm} \times 4.0 \mathrm{~cm} \times 2.0 \mathrm{~cm}$, respectively, and were partially encapsulated. The two tumors removed had gray-white color and soft myxoid. The tumor cells had relatively uniform morphology and consisted of primitive mesenchymal cells in a myxoid background at the microscopic level. At lowpower magnification, the tumor cells were diffusely distributed and were mainly spindle cells (Fig. 2a). Blood vessels were abundant (Fig. 2b), and many fat cells were observed in some areas (Fig. 2c). Infiltration of focal lymphocytes was found in few areas (Fig. 2d). High-power microscopic examination showed that the tumor cells had unclear boundaries, fat and spindle-shaped nuclei, homogeneous chromatin, occasional nucleoli, variable amounts of pale eosinophilic to clear vacuolated cytoplasm, and fissure-like blood vessels (Fig. 2e). The morphology of the recurrent tumor was similar to the first one (Fig. 2f). 
IHC staining results indicated that the tumor cell was extensively nuclear and positive for H3K27me3, B-cell lymphoma 6 corepressor (BCOR), and Bcl-2 (Figs. 3a, b, c). Cluster of differentiation 99 (CD99) showed diffuse reactivity (Fig. 3d). BCL6 showed scattered positive (Fig. 3e). The Ki-67 proliferating index was $20 \%$. The tumor cell was negative for myogenic markers (Desmin and smooth muscle actin), epithelial marker (AE1/AE3 and EMA) (Fig. 3f), endothelial cell marker (CD34), histiocyte marker (CD68), and neural markers (S-100). The tumor cell was negative for neurotrophic receptor tyrosine kinase 1 (NTRK1). Two-color fluorescence in situ hybridization (FISH) with a split ETS variant 6 (ETV6) probe (Vysis, USA) showed the nucleus of red and green signals caused by the absence of the ETV6 gene rearrangement. Two-color FISH with a split BCOR probe (Anbiping, China) showed similar results (Fig. 4).

\section{Literature Review}

\section{Literature}

We collected literature in the GeenMedical, PubMed, Web of Science, and Google Scholar databases regarding PMMTI. The search term used was "primitive myxoid mesenchymal tumor of infancy" OR "primitive myxoid mesenchymal tumor." We downloaded and read the paper for identification when its title or abstract contains the search term. A total of $36 \mathrm{cases}$, including our case, were reported from 2006 to 2019 and collected for analysis. One article examined the expression of Pan-TRK in 210 tumors, including 10 PMMTI cases, and only briefly summarized the clinical information [2]. Other available data regarding clinical characteristics and prognosis are summarized in Table 1.

The disease mostly occurred among people with age less than 1 year. In the 36 cases, 29 and 7 cases were less (79.5\%) and more than 1 year old, respectively. The oldest patient was 4 years old. 17 cases were male, and 18 cases were female. The gender of one patient was unknown. The incidence approximately had equal men and women (Table 2).

In the 36 cases, only one case had unknown tumor site. The best sites for the tumors were the torso and limbs, and 11 cases were found, accounting for $31.4 \%$, followed by paraspinal with 8 cases, accounting for $22.9 \%$. Eight cases were found in head and neck (22.9\%). Six cases were reported in the abdominal cavity (15.8\%). One neoplasm with multiple neonates and one in the scrotum were reported.

In the 26 cases, the tumor sizes ranged from $0.9 \mathrm{~cm}$ to $15 \mathrm{~cm}$. 14 cases of tumors were larger than $5 \mathrm{~cm}$, accounting for $53.9 \%$ and 12 cases of tumors were less than or equal to $5 \mathrm{~cm}$, accounting for $46.1 \%$. In the 36 cases, 19 patients had follow-up visits. 18 patients had relapsed or metastasized tumors. Recurrence or metastasis rate reached $56 \%$. The tumors of three patients were incompletely removed because of their adhesion to the surrounding tissues or multiple tumors. Five patients (19.2\%) died.

Huang evaluated the Pan-TRK protein in 210 tumors, including 10 PMMTI cases of four females and six males, with a median age of 11 months (age range, 3 weeks to 2 years) involving paraspinal/intra-abdominal region $(n=4)$, inguinal region $(n=3)$, head and neck $(n=$ $2)$, and lower limb $(n=1)[2]$.

\section{Discussion}

Since the first report in 2006, the number of PMMTI cases has not exceeded 40. The biological behavior of PMMTI remains unclear. PMMTI develops in newborns or infants aged less than 1 year. In the 36 cases, 29 cases were less than 1 year old. The oldest patient was 4 years old. 17 cases were male, and 18 cases were female. The incidence had approximately equal men and women. The tumor was mainly located in the torso and limbs, paraspinal, head and neck, and abdominal cavity. In the 29 cases, the tumor sizes ranged from $0.9 \mathrm{~cm}$ to $15 \mathrm{~cm}$. 14 tumor cases were larger than $5 \mathrm{~cm}$, accounting for $54 \% .12$ tumor cases were less than or equal to $5 \mathrm{~cm}$, accounting for $46 \%$. Fourteen out of 26 patients had relapsed or metastasized tumor. Recurrence or metastasis rate reached $56 \%$. The tumors of three patients were incompletely removed because of their adhesion to surrounding tissues. Five patients died (19.2\%).

During gross examination, the tumor principally presented as unencapsulated and frequently exhibited focal infiltration. The cut surface usually showed gray-white myxoid. The tumor cells had relatively uniform morphology and consisted of primitive mesenchymal cells in a myxoid background at the microscopic level. The tumor cells were diffusely distributed and were mainly spindle cells. We occasionally found many fat cells and infiltration of focal lymphocytes. The tumor cells had unclear boundaries, fat and spindle-shaped nuclei, homogeneous chromatin, occasional nucleoli, and variable amounts of pale eosinophilic to clear vacuolated cytoplasm. 
PMMTI diagnosis was based on morphologic features. Therefore, it should be distinguished from other tumors that occur in infants and young children. Tumors that frequently need to be identified include CIFS, CCSK, ERMS, EWS/PNET, and ISTURCS. CIFS is a pediatric spindle cell tumor of the soft tissues, and the majority of age is before 2 years. CIFS histologically displays sheets of spindle cells, and its myxoid areas are less than those in PMMTI. Molecular and cytogenetic studies have shown that $t(12,15)$ with ETV6-NTRK3 gene fusion occurs in CIFS [21], but is absent in PMMTI. Bourgeois et al. studied a large series of childhood pediatric spindle cell lesions for ETV6-NTRK3 gene fusions, including 11 cases of CIFS, 13 adult-type fibrosarcoma, and 38 benign spindle cell tumors (including infantile fibromatosis and myofibromatosis). Ten out of 11 cases of CIFS showed the ETV6-NTRK3 gene fusion, whereas none of the 51 other tumors demonstrated this gene fusion [22].

CCSK is an aggressive primary pediatric renal tumor, and the age of occurrence frequently ranges from 2 years to 3 years [23]. CCSK consists of nests of plump ovoid or spindled cells. Its protein profile is characterized by the expression of only the nonspecific marker vimentin. Some studies have shown that cyclin D1 is helpful in distinguishing CCSK from Wilms tumor, rhabdoid tumor, and metanephric adenoma [24,25].

Few studies have found that BCOR internal tandem duplication (ITD) is found in $85 \%$ of CCSK cases [26]. Kao et al. studied 22 ISTURCS, 7 PMMTI, and 4 CCSK for YWHAE-NUTM2B/E through FISH or real-time polymerase chain reaction and BCOR ITD through PCR. The results showed the identification of BCOR ITD in 9 of 22 ISTURCS (40.9\%) and in 6 of 7 PMMTI cases (85.7\%), and YWHAENUTM2B fusion is a rare event in ISTURCS [13]. Santiago et al. confirmed BCOR ITD in five PMMTI cases through PCR and sequencing [17]. Kao at el. showed that BCOR protein is diffused and positive in 13 out of 14 BCOR ITD positive tumors (92.9\%), and all CCSK cases show strong and diffused nuclear BCOR immunoreactivity [13]. BCL6 and BCOR proteins demonstrated diffused nuclear positivity in more than $90 \%$ of tumor cells in all five PMMTI cases, whereas they were negative in all CIFS cases [17]. BCL6 is a molecular target of BCOR and is used as a confirmatory marker [27]. Therefore, the expression levels of BCOR and BCL6 observed in PMMTI can serve as a useful marker.

ERMS occurs in the head, neck, and reproductive areas of infants and young children and should be distinguished from PMMTI. The microscopic characteristics of ERMS includes small round cells, oval or short spindle-shaped mesenchymal cells, and the stroma could be loosely myxoid zones. Positive myogenic IHC markers are evident in ERMS, whereas they are absent in PMMTI. ERMS has no specific molecular genetic changes.

EWS/PNET mainly occurs in the bone and extraskeletal sites. The prevalent age group is young people. It consists of primitive uniform small round cells and rarely shows myxoid changes. Special IHC markers are CD99, Fli1, and NKX2.2, and molecular genetic changes are EWSR1-FLI1 and EWSR1-ERG gene fusions [28, 29, 30].

Another article reported that PMMTI occasionally needs to be identified with undifferentiated myxoid lipoblastoma, but special PLAG1 rearrangement occurs in undifferentiated myxoid lipoblastoma [31].

H3K27me3 is highly expressed and associated with improved patient survival in multiple cancer [32,33]. Lu VM et al. Analyzed H3K27 trimethylation loss in malignant peripheral nerve sheath tumor (MPNST) through systematic review and meta-analysis. The results showed that the incidence of complete H3K27me3 loss is substantial in high-grade MPNST and is low in MPNST-mimics [34]. In this case study, we found that the diffused nuclear expression of H3K27me3 may indicate improved prognosis for patients. This study is the first to investigate H3K27me3 expression in PMMTI.

ISTURCS is usually an exclusionary diagnosis, and its morphology occasionally overlaps with PMMTI and CCSK. However, several differences are found in IHC and molecular genetics.

\section{Conclusion}

We reported a rare case of PMMTI in the scrotum and reviewed all reported PMMTI cases. We found that PMMTI mainly occurs in young children aged less than 1 year, and the ratio of male to female is similar. The main tumor sites are the torso and limbs, followed by paraspinal, head, and neck. Recurrence or metastasis rate reaches $57.7 \%$. The mortality rate is $19 \%$. PMMTI is at least a low-grade malignancy. BCOR, BCL2, BCL6, and CD99 can be used as special IHC markers, and most PMMTI cases exhibit BCOR ITD change (Table 3). H3K27me3 may be used as a new IHC marker for PMMTI.

\section{Abbreviations}


PMMTI: Primitive Myxoid Mesenchymal Tumor of Infancy; H3K27me3: histone H3 at lysine 27; BCOR: B-cell Lymphoma 6 Corepressor; CD99: Cluster of Differentiation 99; NTRK1: Neurotrophic Tyrosine Receptor Kinase 1; FISH: Fluorescence In Situ Hybridization; ETV6: ETS variant 6; CIFS: Congenital-Infantile Fibrosarcoma; ERMS: Embryonal Rhabdomyosarcoma; CCSK: Clear Cell Sarcoma of Kidney; EWS/PNET: Ewing Sarcoma/Primitive Neuroectodermal Tumor; ISTURCS: Infantile Soft Tissue Undifferentiated Round Cell Sarcoma; IHC: Immunohistochemical; CT: Chemotherapy; RT: Radiotherapy; AWD: Alive with disease; NED: No evidence of disease; DFD: Died from disease; NA: Not available; ITD: Internal tandem duplication; MPNST: Malignant Peripheral Nerve Sheath Tumor;

\section{Declarations}

\section{Acknowledgements}

The authors would like to thank our patient for allowing for his case to be presented. We would like to thank Professor Jian Wang, Chief of the Department of Pathology, Shanghai Fudan University Cancer Hospital, Shanghai, China, for his consultation on the case. This work was supported by grant from the National Natural Science Foundation of China (No. 81960485) and Science and Technology Development Project of Xinjiang Production and Construction Corps (2018AB033).

\section{Informed consent statement}

Informed consent was obtained from the patient.

\section{Conflict-of-interest statement}

The authors declare that there is no conflict of interest related to this report.

\section{Ethical statement}

Written informed consent was obtained from the patient. Ethical approval was obtained from the Ethics Committee of the First Affiliated Hospital, School of Medicine, Shihezi University, China, in accordance with the ethical guidelines of the 1975 Declaration of Helsinki.

\section{Authors' contributions}

Yi Liu and Mengqiao Wang performed the histological and IHC evaluation and FISH. Hongwei Dang and Yan Pan was involved in literature review. Chunsen Li, Haiou Zhao Chunxia Liu was drafted the manuscript. All authors read and approved the final manuscript.

\section{Funding}

Not applicable.

\section{Ethics approval and consent to participate}

Written informed consent was obtained from all participants. Ethical approval was obtained from the Ethics Committee of the First Affiliated Hospital, School of Medicine, Shihezi University, China, in accordance with the ethical guidelines of the 1975 Declaration of Helsinki. Written informed consent was obtained from the patient for publication of this case report and any accompanying images. A copy of the written consent is available for review by the Editor in-Chief of this journal.

\section{Declaration of Competing Interest}

Authors have declared that no competing interests exist. This research did not receive any specific grant from funding agencies in the public, commercial, or not-for-profit sectors.

\section{References}

1. Alaggio R, Ninfo V, Rosolen A, Coffin CM: Primitive myxoid mesenchymal tumor of infancy: a clinicopathologic report of 6 cases. The American journal of surgical pathology 2006, 30(3):388-394.

2. Hung YP, Fletcher CDM, Hornick JL: Evaluation of pan-TRK immunohistochemistry in infantile fibrosarcoma, lipofibromatosis-like neural tumour and histological mimics. Histopathology 2018, 73(4):634-644. 
3. Lam J, Lara-Corrales I, Cammisuli S, Somers GR, Pope E: Primitive myxoid mesenchymal tumor of infancy in a preterm infant. Pediatric dermatology 2010, 27(6):635-637.

4. Mulligan L, O'Meara A, Orr D, Eadie P, Hayes R, McDermott M: Primitive myxoid mesenchymal tumor of infancy: a report of a further case with locally aggressive behavior. Pediatric and developmental pathology : the official journal of the Society for Pediatric Pathology and the Paediatric Pathology Society 2011, 14(1):75-79.

5. Gong Q, Wang Z, Li X, Fan Q: Primitive myxoid mesenchymal tumor of infancy: report of two cases and review of the literature. Pathology international 2012, 62(8):549-553.

6. Su TC, Hwang MJ, Li CF, Wang SC, Lee CH, Chen CJ: A rare malignant tumor of scalp in a 3-month-old Taiwanese infancy: case report of primitive myxoid mesenchymal tumor of infancy with molecular study. Medical molecular morphology 2013, 46(2):109113.

7. Saito A, Taketani T, Kanai R, Kanagawa T, Kumori K, Yamamoto $\mathrm{N}$ et al: A case with sacrococcygeal primitive myxoid mesenchymal tumor of infancy: a case report and review of the literature. Journal of pediatric hematology/oncology 2013, 35(7):e280-282.

8. Cuthbertson DW, Caceres K, Hicks J, Friedman EM: A cooperative approach to diagnosis of rare diseases: primitive myxoid mesenchymal tumor of infancy. Annals of clinical and laboratory science 2014, 44(3):310-316.

9. Cipriani NA, Ryan DP, Nielsen GP: Primitive myxoid mesenchymal tumor of infancy with rosettes: a new finding and literature review. International journal of surgical pathology 2014, 22(7):647-651.

10. Wang H, Liu Q, Wang J, He H, Ma Y, Chen L: [Primitive myxoid mesenchymal tumor of infancy: a clinicopathologic study of 3 additional cases]. Zhonghua bing li xue za zhi = Chinese journal of pathology 2014, 43(6):375-378.

11. Guilbert MC, Rougemont AL, Samson Y, Mac-Thiong JM, Fournet JC, Soglio DB: Transformation of a primitive myxoid mesenchymal tumor of infancy to an undifferentiated sarcoma: a first reported case. Journal of pediatric hematology/oncology 2015, 37(2):e118-120.

12. Foster JH, Vasudevan SA, John Hicks M, Schady D, Chintagumpala M: Primitive Myxoid Mesenchymal Tumor of Infancy Involving Chest Wall in an Infant: A Case Report and Clinicopathologic Correlation. Pediatric and developmental pathology : the official journal of the Society for Pediatric Pathology and the Paediatric Pathology Society 2016, 19(3):244-248.

13. Mao ST, Li B, Wang D: [A case of primitive myxoid mesenchymal tumor of infancy with ascites as the initial symptom]. Zhonghua er ke za zhi $=$ Chinese journal of pediatrics 2016, 54(6):467-469.

14. Kao YC, Sung YS, Zhang L, Jungbluth AA, Huang SC, Argani P et al: BCOR Overexpression Is a Highly Sensitive Marker in Round Cell Sarcomas With BCOR Genetic Abnormalities. The American journal of surgical pathology 2016, 40(12):1670-1678.

15. Zhang F, Emberson LL: Using pupillometry to investigate predictive processes in infancy. Infancy : the official journal of the International Society on Infant Studies 2020, 25(6):758-780.

16. Cramer SL, Li R, Ali S, Bradley JA, Kim HK, Pressey JG: Successful Treatment of Recurrent Primitive Myxoid Mesenchymal Tumor of Infancy With BCOR Internal Tandem Duplication. Journal of the National Comprehensive Cancer Network : JNCCN 2017, 15(7):868871.

17. Santiago T, Clay MR, Allen SJ, Orr BA: Recurrent BCOR internal tandem duplication and BCOR or BCL6 expression distinguish primitive myxoid mesenchymal tumor of infancy from congenital infantile fibrosarcoma. Mod Pathol 2018, 31(2):374.

18. Wu D, Zheng J, Mao G, Hu W, Ye X, Linhardt RJ et al: Rethinking the impact of RG-I mainly from fruits and vegetables on dietary health. Critical reviews in food science and nutrition 2020, 60(17):2938-2960.

19. Chacon D, Correa C, Luengas JP: Mesenteric Primitive Myxoid Mesenchymal Tumor in a 7-Month-Old Boy. Journal of pediatric hematology/oncology 2018, 40(4):e260-e262.

20. Saeed AA, Riaz Q, Din NU, Altaf S: Primitive myxoid mesenchymal tumor of infancy with brain metastasis: first reported case. Child's nervous system : ChNS : official journal of the International Society for Pediatric Neurosurgery 2019, 35(2):363-368.

21. Knezevich SR, McFadden DE, Tao W, Lim JF, Sorensen PH: A novel ETV6-NTRK3 gene fusion in congenital fibrosarcoma. Nature genetics 1998, 18(2):184-187.

22. Bourgeois JM, Knezevich SR, Mathers JA, Sorensen PH: Molecular detection of the ETV6-NTRK3 gene fusion differentiates congenital fibrosarcoma from other childhood spindle cell tumors. The American journal of surgical pathology 2000, 24(7):937946.

23. Argani P, Perlman EJ, Breslow NE, Browning NG, Green DM, D'Angio GJ et al: Clear cell sarcoma of the kidney: a review of 351 cases from the National Wilms Tumor Study Group Pathology Center. The American journal of surgical pathology 2000, 24(1):4-18.

Page 6/12 
24. Jet Aw S, Hong Kuick C, Hwee Yong M, Wen Quan Lian D, Wang S, Liang Loh AH et al: Novel Karyotypes and Cyclin D1 Immunoreactivity in Clear Cell Sarcoma of the Kidney. Pediatric and developmental pathology : the official journal of the Society for Pediatric Pathology and the Paediatric Pathology Society 2015, 18(4):297-304.

25. Mirkovic J, Calicchio M, Fletcher CD, Perez-Atayde AR: Diffuse and strong cyclin D1 immunoreactivity in clear cell sarcoma of the kidney. Histopathology 2015, 67(3):306-312.

26. Ueno-Yokohata H, Okita H, Nakasato K, Akimoto S, Hata J, Koshinaga T et al: Consistent in-frame internal tandem duplications of BCOR characterize clear cell sarcoma of the kidney. Nature genetics 2015, 47(8):861-863.

27. Parham DM: Fibroblastic and myofibroblastic tumors of children: new genetic entities and new ancillary testing. F1000Research 2018, 7.

28. Kim SK, Park YK: Ewing sarcoma: a chronicle of molecular pathogenesis. Human pathology 2016, 55:91-100.

29. Ewing sarcoma. Nature reviews Disease primers 2018, 4(1):6.

30. Hung YP, Fletcher CD, Hornick JL: Evaluation of NKX2-2 expression in round cell sarcomas and other tumors with EWSR1 rearrangement: imperfect specificity for Ewing sarcoma. Mod Pathol 2016, 29(4):370-380.

31. Warren M, Turpin BK, Mark M, Smolarek TA, Li X: Undifferentiated myxoid lipoblastoma with PLAG1-HAS2 fusion in an infant; morphologically mimicking primitive myxoid mesenchymal tumor of infancy (PMMTI)-diagnostic importance of cytogenetic and molecular testing and literature review. Cancer genetics 2016, 209(1-2):21-29.

32. Benard A, Goossens-Beumer IJ, van Hoesel AQ, Horati H, Putter H, Zeestraten EC et al: Prognostic value of polycomb proteins EZH2, BMI1 and SUZ12 and histone modification H3K27me3 in colorectal cancer. PloS one 2014, 9(9):e108265.

33. Lu VM, Marek T, Gilder HE, Puffer RC, Raghunathan A, Spinner RJ et al: H3K27 trimethylation loss in malignant peripheral nerve sheath tumor: a systematic review and meta-analysis with diagnostic implications. Journal of neuro-oncology 2019, 144(3):433443.

\section{Tables}

Table 1 Cases of PMMTI with clinicopathologic features and survival data in reviewed literature 


\begin{tabular}{|c|c|c|c|c|c|c|c|c|c|}
\hline Case & $\begin{array}{l}\text { Reported } \\
\text { year }\end{array}$ & Author & Age/Sex & Site & $\begin{array}{l}\text { Size } \\
(\mathrm{cm})\end{array}$ & Treatment & $\begin{array}{l}\text { Recurrence site, } \\
\text { time after } \\
\text { diagnosis }\end{array}$ & Outcome & $\begin{array}{l}\text { Follow } \\
\text { up }\end{array}$ \\
\hline 1 & $2006^{1}$ & Alaggio $\mathrm{R}$ & $5 \mathrm{~m} / \mathrm{M}$ & Larynx & 2.5 & $\begin{array}{l}\text { Surgery, } \\
\text { CT }\end{array}$ & $\begin{array}{l}\text { Larynx, } 1 \text { y, } \\
\text { perilaryngeal } \\
\text { soft tissue, } \\
\text { salivary gland, } \\
\text { and skin, } 2,3 \text {, } \\
\text { and } 4 \mathrm{y}\end{array}$ & DFD & $5 y$ \\
\hline 2 & & & $1 \mathrm{~m} / \mathrm{M}$ & Right thigh & 15 & $\begin{array}{l}\text { Surgery, } \\
\text { CT }\end{array}$ & $\begin{array}{l}\text { Inguinal soft } \\
\text { tissue, left } \\
\text { hepatic nodule } \\
\text { (not confirmed } \\
\text { histologically) }\end{array}$ & NED & $4 y$ \\
\hline 3 & & & $2 \mathrm{w} / \mathrm{M}$ & Forearm & 10 & Surgery & None & NED & $1 \mathrm{y}$ \\
\hline 4 & & & $2 \mathrm{~m} / \mathrm{M}$ & $\begin{array}{l}\text { Paraspinal soft } \\
\text { tissue }\end{array}$ & 5.5 & Surgery & $\begin{array}{l}\text { Distant } \\
\text { metastasis, } 6 \\
\mathrm{~m}\end{array}$ & NA & NA \\
\hline 5 & & & $3 \mathrm{w} / \mathrm{F}$ & $\begin{array}{l}\text { Supraclavicular } \\
\text { soft tissue }\end{array}$ & 5 & Surgery & $\begin{array}{l}\text { Supraclavicular } \\
\text { soft tissue, } 4 \mathrm{~m}\end{array}$ & AWD & $4 \mathrm{~m}$ \\
\hline 6 & & & Newborn/F & $\begin{array}{l}\text { Back, neck, } \\
\text { chest, abdomen, } \\
\text { spinal canal }\end{array}$ & 15 & $\begin{array}{l}\text { Surgery } \\
\text { (partial } \\
\text { resection) }\end{array}$ & $\begin{array}{l}\text { Persistent } \\
\text { disease after } \\
\text { partial } \\
\text { resection }\end{array}$ & $\begin{array}{l}\text { DFD } \\
\text { (sepsis) }\end{array}$ & $6 w$ \\
\hline 7 & $2010^{2}$ & Lam J & $3 \mathrm{~m} / \mathrm{M}$ & Back & 3.5 & Surgery & None & NED & $3.25 y$ \\
\hline 8 & $2011^{3}$ & Mulligan L & $8 \mathrm{~m} / \mathrm{F}$ & Hand & 2 & $\begin{array}{l}\text { Surgery, } \\
\text { CT }\end{array}$ & Hand, $3 \mathrm{~m}$ & AWD & $5 y$ \\
\hline 9 & $2012^{4}$ & Gong Q & $5 \mathrm{~m} / \mathrm{M}$ & $\begin{array}{l}\text { Soft tissue } \\
\text { around trachea } \\
\text { and thyroid } \\
\text { gland }\end{array}$ & 4.5 & Surgery & $\begin{array}{l}\text { Soft tissue of } \\
\text { neck, } 2 \mathrm{~m} \text {; } \\
\text { larynx, } 5 \mathrm{~m}\end{array}$ & AWD & $5 \mathrm{~m}$ \\
\hline 10 & & & $3 d / F$ & $\begin{array}{l}\text { Dorsal lumbar } \\
\text { region }\end{array}$ & 6 & Surgery & $\begin{array}{l}\text { Lumbar spinal } \\
\text { canal, } 1 \mathrm{~m}\end{array}$ & NA & NA \\
\hline 11 & $2013^{5}$ & Su TC & $3 \mathrm{~m} / \mathrm{M}$ & Scalp & 0.9 & Surgery & None & AWD & $1.5 \mathrm{y}$ \\
\hline 12 & $2013^{6}$ & Saito A & $19 \mathrm{~m} / \mathrm{F}$ & $\begin{array}{l}\text { Sacrococcygeal } \\
\text { region }\end{array}$ & 4.5 & Surgery & None & NED & $2 y$ \\
\hline 13 & $2014^{7}$ & $\begin{array}{l}\text { Cuthbertson } \\
\text { DW }\end{array}$ & $3 y / F$ & Hard palate & 7 & $\begin{array}{l}\text { Surgery, } \\
\text { CT }\end{array}$ & $\begin{array}{l}\text { Hard palate } \\
\text { and maxillary } \\
\text { sinus }\end{array}$ & NED & $9 \mathrm{~m}$ \\
\hline 14 & $2014^{8}$ & Cipriani NA & $15 \mathrm{~m} / \mathrm{F}$ & left ankle & 2.0 & Surgery & None & NED & $1 \mathrm{~m}$ \\
\hline 15 & $2014^{9}$ & Wang $\mathrm{H}$ & $4 \mathrm{y} / \mathrm{M}$ & Neck & 6.5 & Surgery & $\begin{array}{l}\text { Lumber regions } \\
\text { recur twice }\end{array}$ & DFD & $2 y$ \\
\hline 16 & & & $2 \mathrm{~d} / \mathrm{M}$ & Neck & 5.5 & Surgery & None & NED & NA \\
\hline 17 & & & $3 \mathrm{~m} / \mathrm{F}$ & Waist & 2.8 & Surgery & None & NED & NA \\
\hline 18 & $2015^{10}$ & Guilbert MC & $8 \mathrm{~m} / \mathrm{F}$ & Left neck & 7.5 & $\begin{array}{l}\text { Surgery, } \\
\text { CT }\end{array}$ & $\begin{array}{l}\text { Left neck, } 3 \text { m; } \\
\text { left } \\
\text { supraclavicular } \\
\text { lymph nodes, } \\
46 \text { m; } \\
\text { numerous } \\
\text { distant } \\
\text { metastases, } 7 \\
\text { m }\end{array}$ & AWD & $13 \mathrm{~m}$ \\
\hline 19 & $2016^{11}$ & Foster JH & $3 \mathrm{~m} / \mathrm{F}$ & Chest wall & 7 & Surgery & None & NED & $20 \mathrm{~m}$ \\
\hline 20 & & Mao ST & $2 y / F$ & $\begin{array}{l}\text { Abdominal } \\
\text { Page 8/1 }\end{array}$ & 6 & Surgery & Persistent & DFD & $6 w$ \\
\hline
\end{tabular}




\begin{tabular}{|c|c|c|c|c|c|c|c|c|c|}
\hline & $2016^{12}$ & & & $\begin{array}{l}\text { cavity, } \\
\text { Abdominal wall }\end{array}$ & & $\begin{array}{l}\text { (partial } \\
\text { resection) }\end{array}$ & $\begin{array}{l}\text { disease after } \\
\text { partial } \\
\text { resection }\end{array}$ & & \\
\hline 21 & $2016^{13}$ & Kao YC & $9 \mathrm{~m} / \mathrm{M}$ & Abdominal wall & NA & NA & $\begin{array}{l}\text { Local } \\
\text { recurrence, } 5 \mathrm{~m}\end{array}$ & NA & NA \\
\hline 22 & & & $6 \mathrm{~m} / \mathrm{M}$ & Retroperitoneum & NA & NA & NA & NA & NA \\
\hline 23 & & & $10 \mathrm{~m} / \mathrm{F}$ & $\begin{array}{l}\text { Abdominal } \\
\text { cavity }\end{array}$ & NA & NA & NA & NA & NA \\
\hline 24 & & & $4 \mathrm{~m} / \mathrm{F}$ & Paravertebral & NA & NA & NA & NA & NA \\
\hline 25 & & & $1 \mathrm{y} / \mathrm{M}$ & Thigh & NA & NA & NA & NA & NA \\
\hline 26 & $2016^{14}$ & Burns C & Neonate/NA & $\begin{array}{l}\text { Paraspinal soft } \\
\text { tissue (L1-L5) }\end{array}$ & NA & $\begin{array}{l}\text { Surgery, } \\
\text { CT }\end{array}$ & $\begin{array}{l}\text { intra and } \\
\text { extraspinal, } 3 \\
\text { m }\end{array}$ & NA & NA \\
\hline 27 & $2017^{15}$ & Cramer SL & $13 \mathrm{~m} / \mathrm{F}$ & Paraspinal & NA & $\begin{array}{l}\text { Surgery, } \\
\text { CT, RT }\end{array}$ & $\begin{array}{l}\text { Multiple } \\
\text { recurrences }\end{array}$ & NED & $12 \mathrm{~m}$ \\
\hline 28 & $2017^{16}$ & Santiago T & $1 \mathrm{w} / \mathrm{M}$ & $\begin{array}{l}\text { Paraspinal } \\
\text { (occipital) }\end{array}$ & 10.2 & NA & NA & NA & NA \\
\hline 29 & & & $9 \mathrm{~m} / \mathrm{F}$ & Back & 2.5 & NA & NA & NA & NA \\
\hline 30 & & & $8 \mathrm{~m} / \mathrm{F}$ & $\begin{array}{l}\text { Paraspinal (T9 } \\
\text { to L3) }\end{array}$ & NA & NA & NA & NA & NA \\
\hline 31 & & & $13 \mathrm{~m} / \mathrm{F}$ & $\begin{array}{l}\text { Paraspinal (L2 } \\
\text { to S2) }\end{array}$ & NA & NA & NA & NA & NA \\
\hline 32 & & & $2 \mathrm{~m} / \mathrm{M}$ & Left foot & 3.4 & NA & NA & NA & NA \\
\hline 33 & $2017^{17}$ & Zhang D & $2 y / F$ & $\begin{array}{l}\text { Abdominal } \\
\text { cavity (Involved } \\
\text { omentum and } \\
\text { intestinal wall) }\end{array}$ & 5.0 & $\begin{array}{l}\text { Surgery } \\
\text { (partial } \\
\text { resection) }\end{array}$ & $\begin{array}{l}\text { Persistent } \\
\text { disease after } \\
\text { partial } \\
\text { resection }\end{array}$ & DFD & $2 \mathrm{~m}$ \\
\hline 34 & $2018^{18}$ & Chacon D & $7 \mathrm{~m} / \mathrm{M}$ & $\begin{array}{l}\text { Abdominal } \\
\text { cavity }\end{array}$ & 10 & Surgery & NA & NA & NA \\
\hline 35 & $2019^{19}$ & Saeed AA & $2 \mathrm{y} / \mathrm{M}$ & NA & NA & $\begin{array}{l}\text { Surgery, } \\
\text { CT }\end{array}$ & $\begin{array}{l}\text { Brain } \\
\text { metastasis, NA }\end{array}$ & NA & NA \\
\hline 36 & & Our case & $1 \mathrm{y} / \mathrm{M}$ & scrotum & 6.0 & Surgery & $\begin{array}{l}\text { Local } \\
\text { recurrence, } 1 \text { m }\end{array}$ & NED & 7 m \\
\hline
\end{tabular}

PMMTI, Primitive Myxoid Mesenchymal Tumor of Infancy; M, Male; F, Female; CT, Chemotherapy; RT, Radiotherapy; AWD, Alive with disease; NED, No evidence of disease; DFD, Died from disease; NA, Not available; $d$ = day; $w=$ week; $m=m o n t h ; y=y e a r$

Table 2 Demographics and characteristics of reported PMMTI cases (36 cases). 


\begin{tabular}{|ll|}
\hline Background data & Total cases \\
\hline Age & $\mathrm{N}=36$ \\
\hline$\leq 1$ year & $29(80.6 \%)$ \\
\hline 1year & $7(19.4 \%)$ \\
\hline Sex & $\mathrm{N}=35$ \\
\hline Male & $17(48.6 \%)$ \\
\hline Female & $18(51.4 \%)$ \\
\hline Location & $\mathrm{N}=35$ \\
\hline Head and neck & $8(22.9 \%)$ \\
\hline Abdominal cavity & $11(31.4 \%)$ \\
\hline Paravertebral & $6(17.1 \%)$ \\
\hline Others & $8(22.9 \%)$ \\
\hline Size & $2(5.7 \%)$ \\
\hline$\leq 2 \mathrm{~cm}$ & $\mathrm{~N}=26$ \\
\hline $2-5 \mathrm{~cm}$ & $3(11.6 \%)$ \\
\hline$\geq 5 \mathrm{~cm}$ & $9(34.7 \%)$ \\
\hline Recurrence and metastasis & $18(\mathrm{n}=26)(58 \%)$ \\
\hline Died & $5(\mathrm{n}=26)(20 \%)$ \\
\hline
\end{tabular}

Table 3 Summary of IHC and genetic alteration of infant soft tissue round cell sarcoma.

\begin{tabular}{|lll|}
\hline Type & Specific IHC markers & Characteristic molecular genetic alteration \\
\hline PMMTI & BCOR, BCl-2, BCL-6, CD99, H3K27me3 & BCOR ITD \\
\hline CCSK & BCOR & BCOR ITD \\
\hline CIFS & $/$ & ETV6-NTRK3 \\
\hline EWS/PNET & CD99, Fli1, NXK2.2 & EWS-ERG, EWS-FLI1 \\
\hline ERMS & Desmin, MyoD1, myogenin & $/$ \\
\hline ISTURCS & $/$ & Partial BCOR ITD \\
\hline
\end{tabular}

PMMTI, Primitive Myxoid Mesenchymal Tumor of Infancy; CCSK, Clear Cell Sarcoma of Kidney; CIFS, Congenital-Infantile Fibrosarcoma; ISTURCS, Infantile Soft Tissue Undifferentiated Round Cell Sarcoma; EWS/PNET, Ewing Sarcoma/ Primitive Neuroectodermal Tumor.

\section{Figures}




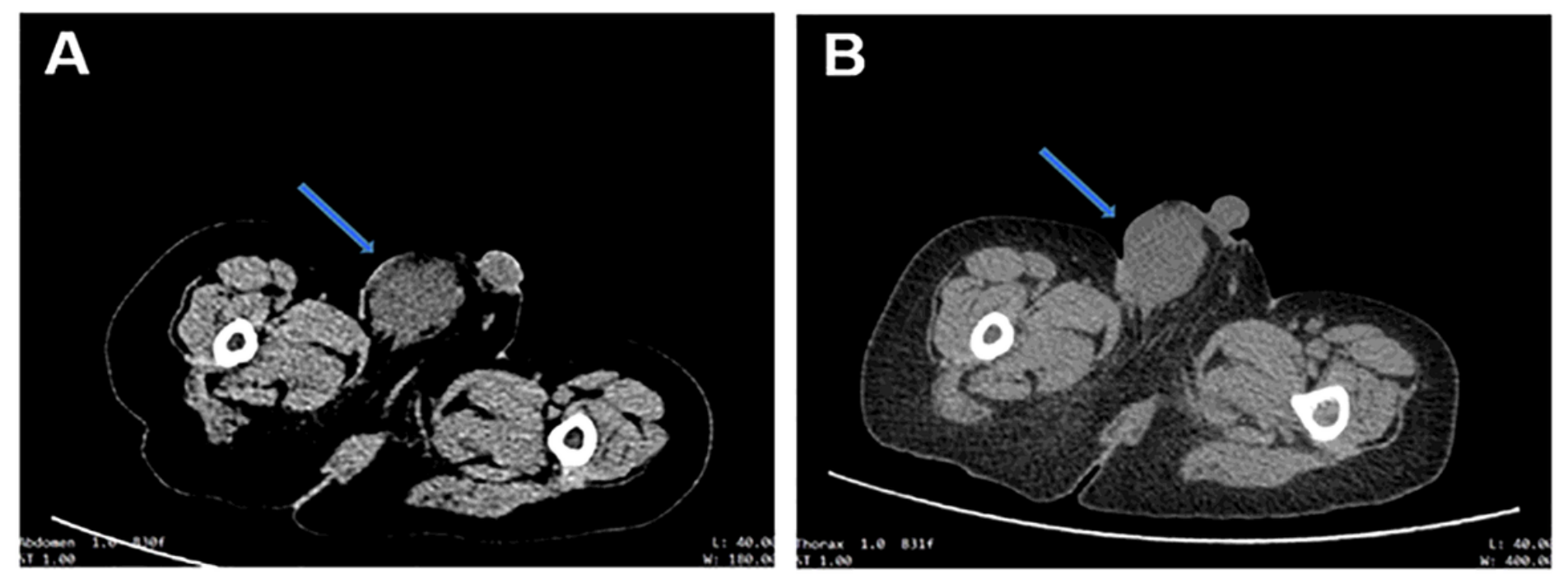

\section{Figure 1}

Imaging findings of the patient. CT scan reveals an abnormal lamellar density mass of $4 \mathrm{~cm} \times 3 \mathrm{~cm}$ and $4 \mathrm{~cm} \times 2 \mathrm{~cm}$ (arrow) in the right groin for the first occurrence (a) and recurrence (b), respectively.

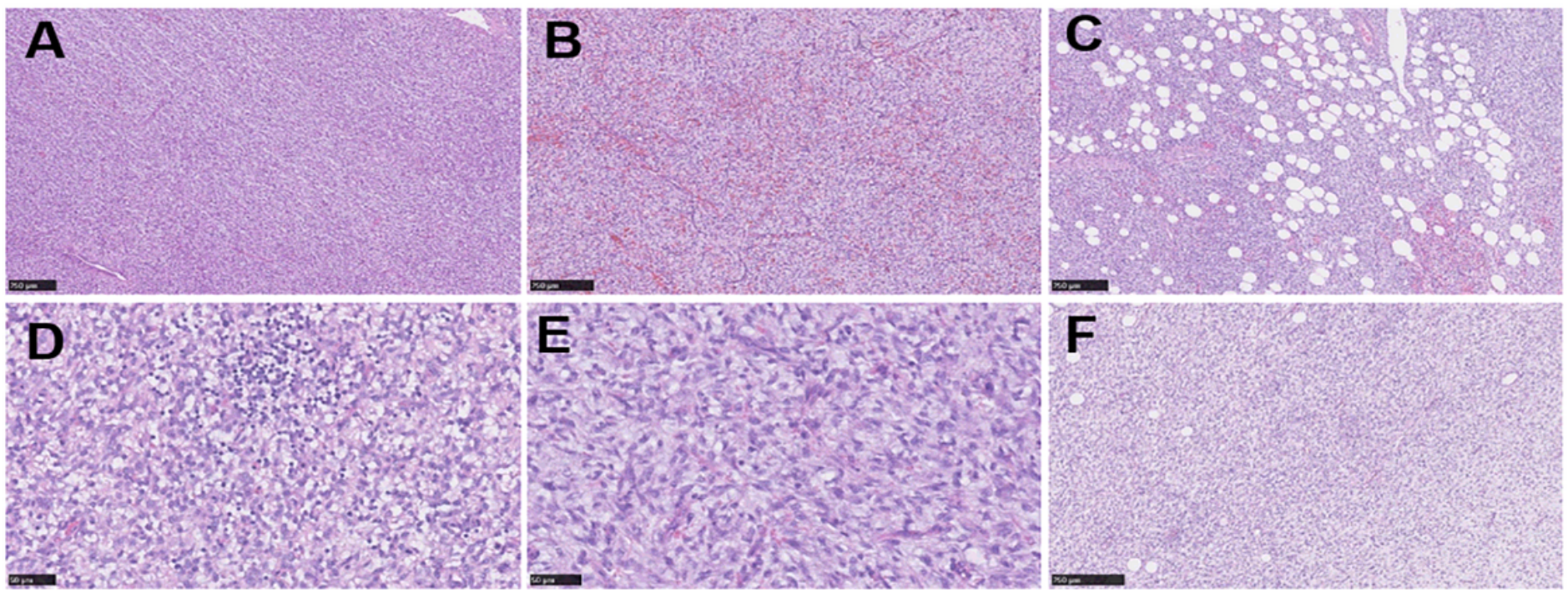

\section{Figure 2}

Morphologic spectrum of PMMTI. PMMTI is diffusely distributed and mainly contains spindle cells (a), blood vessels are abundant in some areas (b). Many fat cells are found in some areas (c). Focal lymphocytes are observed in few areas (d). At high magnification, the blood vessels are fissure-like, the tumor cells have unclear boundaries, with fat and spindle-shaped nuclei and occasional nucleoli. Tumor interstitial mucus is abundant (e). The morphology of the recurrent tumor is similar to the first one (f). 


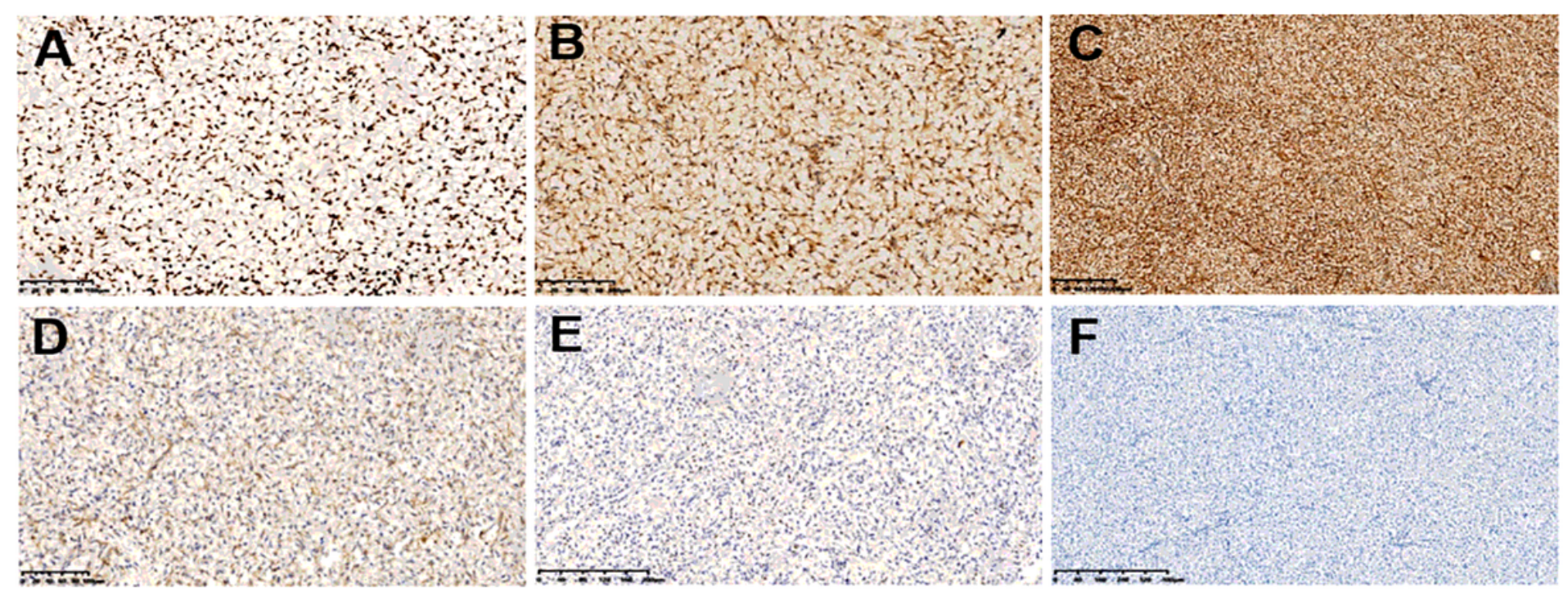

\section{Figure 3}

IHC staining. The tumor cell is extensively nuclear and positive for H3K27me3 (a), BCOR (b), and Bcl-2 (c). The tumor cells have weak and indistinct immunostaining for CD99 (d). BCL6 is scattered nuclear positive (e). The tumor cell is negative for EMA (f).
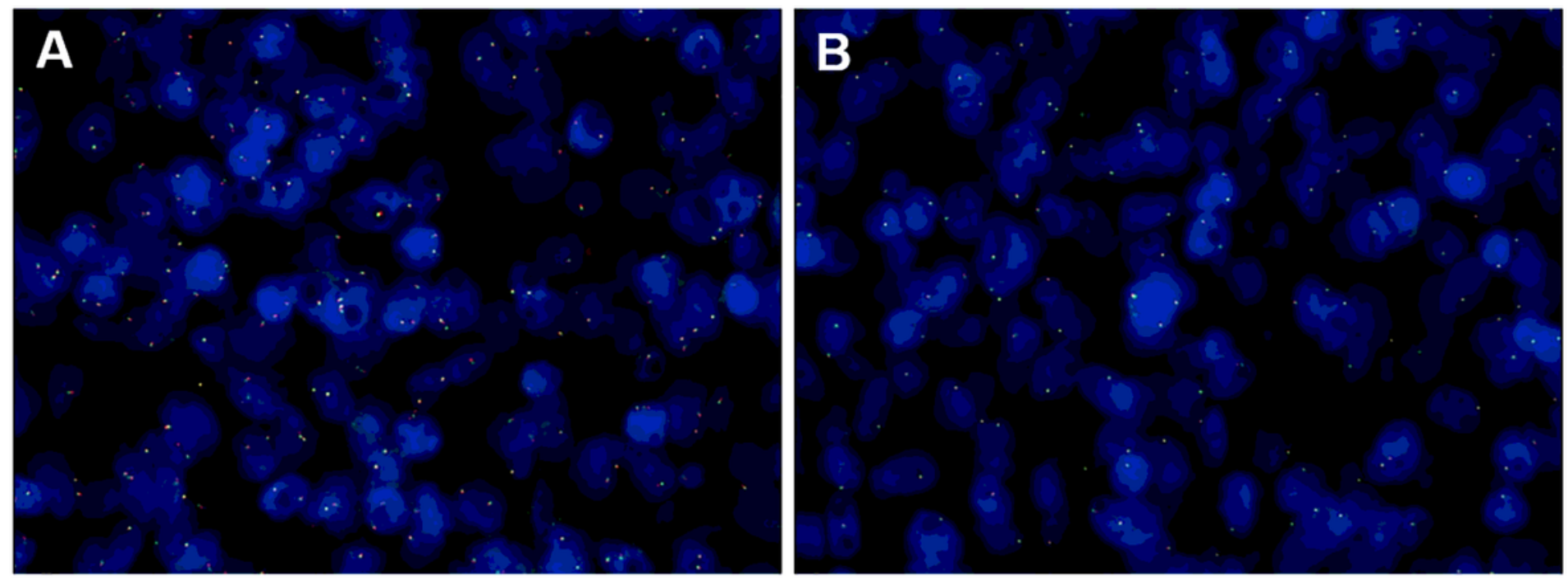

\section{Figure 4}

FISH shows no ETV6 rearrangement, with combined red and green signals (a). FISH also shows no BCOR rearrangement (b).

\section{Supplementary Files}

This is a list of supplementary files associated with this preprint. Click to download.

- CAREchecklistEnglish2013.pdf 